\title{
IMPACT OF Conocarpus erectus L. FERTILIZER, AND SOME MICRONUTRIENTS ON GROWTH AND PRODUCTION OF POTATO
}

\author{
N. H. A. Al-Dulaimi \\ Researcher \\ Mayoralty of Baghdad \\ Al-Shaab Municipality \\ N. J. K. Al-Amri \\ Assist. Prof. \\ College of Agricultural Engineering Sciences \\ University of Baghdad
}

Najah.Hamid1005@coagri.uobaghdad.edu.iq

\section{ABSTRACT}

This study was aimed to determine the impact of Conocarpus erectus $\mathbf{L}$. compost fertilizer, and some micronutrients on growth and production of potato. This research was conducted at one of the fields of the College of Agricultural Engineering Sciences - University of Baghdad. The experiment was implemented using factorial arrangement (4X3X3) within randomized complete block design with three replicates. Conocarpus fertilizer was represented the first factor with three levels $(7.5,15,30$ ton.ha $\left.^{-1}\right)$, which symbolized $(\mathrm{C} 2, \mathrm{C} 3, \mathrm{C} 4)$. Chemical fertilizer as recommended dose as a control, which symbolized (C1). The second factor was foliar spraying with three levels of iron $\left(0,100,200 \mathrm{mg} . \mathrm{L}^{-1}\right)$, which symbolized (F0, F1, F2). The third factor is foliar spraying with three levels of boron $(0,50,100$ mg. $\left.\mathrm{L}^{-1}\right)$, which symbolized (B0, B1, B2). The statistical analysis showed superiority of $\mathrm{C} 3$ in producing significant values of the studied traits such as, leaf area $\left(154.77,187.93 \mathrm{dcm}^{2}\right)$ for fall and spring seasons respectively, plant yield $(649.7 \mathrm{gm}$.) for fall season only. Also the results revealed the significant impact of F2 treatment in producing high leaf area $\left(153.63,177.22 \mathrm{dcm}^{2}\right)$ for fall and spring seasons respectively. B2 treatment demonstrated significant values in producing high starch percentage $(10.09 \%, 10.85 \%)$ for fall and spring seasons respectively, The results that obtained from triple interaction exhibited significant superiority of treatments C1F1B2 and C3F2B0 in producing the highest plant yield $(811 \mathrm{~g}, 1239.2 \mathrm{~g}$.) for both seasons respectively.

Keywords: Buttonwood, iron, boron, composition, foliar feeding

*Part of Ph.D. dissertation of the $1^{\text {st }}$ author

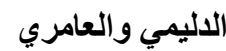

مجلة العلوم الزراعية العراقية - 2020 :51: 1305 (3):865

تأثير التسميد بمخلفات الكونوكاريس المتحلة ورش بعض العناصر الصغرى في نمو وإنتاجية البطاطا

$$
\begin{aligned}
& \text { نبيل جواد كاظم العامري } \\
& \text { استاذ مساعد } \\
& \text { كلية علوم الهندسة الزراعية/جامعة بغداد }
\end{aligned}
$$

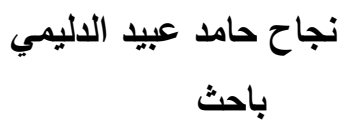

المانة بغداد/ بلاية الثعب

المستخلص

تهذف الدراسة لكثف تأثثر التسميد بمخلفات الكونوكاريس المتحللة ورش بعض العناصر الصغرى في نمو وانتاجية البطاطا. نفنت تجرية حقلية في احد حقول كلية علوم الهندسة الزراعية/جامعة بغداد. طُّبت تجربة عاملية (3X3X4) حسب تصميم القطاعات الكاملة المعثاة

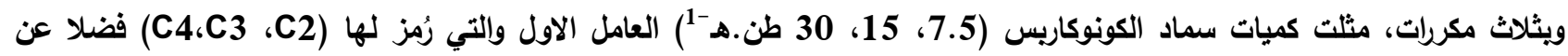

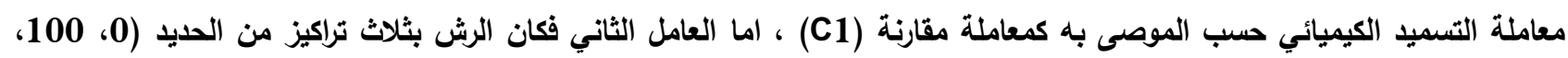

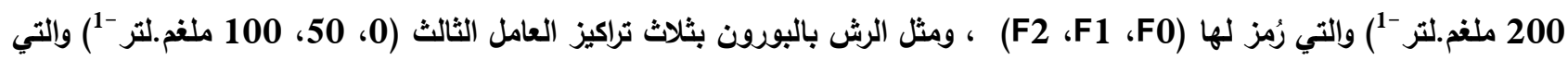

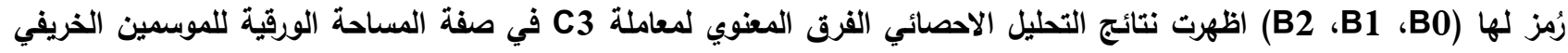

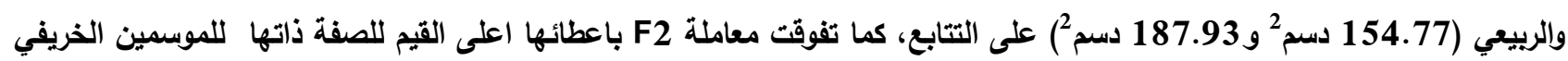

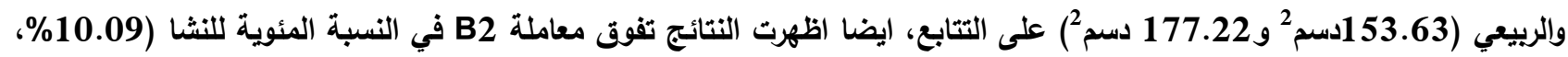
10.85\%) للموسمين الخريفي والريبعي، اما عن نتائج التداخل الثلاثي فقد تفوقت المعاملات

$$
\begin{aligned}
& \text { حاصل نبات (811 غم، } 1239.2 \text { غم) للموسمين الخريفي والربيعي على التتابع. } \\
& \text { الكلمات المفتاحية: نبات الامس، حديد، بورون، تحلل، التغذية الورقية } \\
& \text { البحث مستل من اطروحة دكتوراه للباحث الاول }
\end{aligned}
$$

*Received:23/8/2019, Accepted:18/11/2019 


\section{INTRODUCTION}

Potato plant (Solanum tuberosum L.) belongs to Solanaceae family considered one of the most crucial vegetable crops in worldwide. It comes after cereals in daily human consumption. Potato classified as a starchy veggies that has a large amount of starch and decent amounts of vitamins $\mathrm{C}, \mathrm{A}$, and $\mathrm{B}$ in addition to minerals such as potassium and phosphorus (8). Recycling pruning wastes of Conocarpus trees that planted abundantly by composting process have dual advantages. First, getting rid of their heavy biomass that affects the environment in a large scale if it gets burned. Second, having a high quality compost that serves as a fertilizer (13), and carbon sequencer (12). As a result, there are many studies focused on Conocarpus compost in Middle East region. Alkoaik et al (3) noticed significant increasing in emergence index for radish seeds when planted in composted Conocarpus media. Usman et al (22) mentioned that adding Conocarpus bioachar $(8 \% \mathrm{w} / \mathrm{w})$ to soil mitigated salt stress on tomato plant. Moreover, it was caused increasing in yield $(43.3 \%)$ in comparing to control treatment. The physiologists revealed the major role of micronutrient in plants especially iron and boron. Iron has multifunction in plants, but the most essential one is that it is the main component in heme proteins and $\mathrm{Fe}-\mathrm{S}$ proteins. The mentioned proteins play a vital role in photosynthesis and respiration. In addition, iron is crucial to preserve the structure and function of chloroplast (21). Boron has a significant task in nucleic acids metabolism and DNA synthesis (6). Moreover, it facilitates the efflux of inorganic ions across root tissues (21). Many researches emphasized the importance of foliar application for supplying potato plants of its needs from minerals and nutrients $(17,19)$. Moinuddin et al (15) reported that spraying potato plant with a fertilizer content iron and boron increased the plant height, number of leaves, and root length. Manjunath et al (14) showed that foliar spraying with fertilizer had both of iron and boron with organic manure increased dry matter and total sugar content. As what mentioned previously this study aimed to manufacture a high quality fertilizer from pruning residues of Conocarpus plant after composition and experiment it for the first time on the growth and yield of potato plant. In addition to study the effect of iron and boron and their interaction with Conocarpus fertilizer on the growth and yield of potato plant.

\section{MATERIALS AND METHODS}

This research was conducted at research station (A) College of Agricultural Engineering Sciences, University of Baghdad (Al-Jadiryah). Table 1 shows the chemical and physical properties of the soil for the two seasons. The field divided in to beds with 1.5 $\mathrm{m}$ length and $1 \mathrm{~m}$ width (the plot area $1.5 \mathrm{~m}^{2}$ ). Each plot has 12 plants with $0.25 \mathrm{~m}$ in between. The field was under drip irrigation system. The tubers of potato var. Arizona (from Al-Awrad agricultural company) were planted during spring and fall seasons in $11 / 9 / 2018$ and 18/1/2019 respectively. The experiment was implemented factorial arrangement (4X3X3) within randomized complete block design with three replicates. Conocarpus fertilizer was represented the first factor with three levels added to the soil within planting $\left(7.5,15,30\right.$ ton.ha $\left.^{-1}\right)$ which symbolized (C2, C3, C4). In addition to chemical fertilizer as recommended dose (240N, 120P, 400K kg.ha ${ }^{-1}$ ) (2) as a control, which symbolized (C1). Table 2 shows the chemical and physical properties of Conocarpus fertilizer which was prepared according to Al-Zaidy (4). The second factor is foliar spraying with three levels of iron $(0$, 100, $\left.200 \mathrm{mg} . \mathrm{L}^{-1}\right)\left(\mathrm{FeSO}_{4} 20 \% \mathrm{Fe}\right.$ as a source of iron) which symbolized (F0, F1, F2). The third factor is foliar spraying with three levels of boron $\left(0,50,100 \mathrm{mg} . \mathrm{L}^{-1}\right)\left(\mathrm{H}_{3} \mathrm{BO}_{3} 17 \% \mathrm{~B}\right.$ as a source of boron) which symbolized (B0, B1, B2). The first spraying was after 45 days from planting (Active vegetative growth stage).The second spraying was after 15 days from the first spraying (Tubers initiation stage). The third spraying was after 15 days from the second spraying (Tubers enlargement stage). The characters studied were, plant height $(\mathrm{cm})$, leaf area, $\quad \operatorname{plant}^{-1}\left(\mathrm{dcm}^{2}\right.$.plant $\left.{ }^{-1}\right)$,total tubers.plant $\mathrm{t}^{-1}$, plant yield (kg.plant $\left.{ }^{-1}\right)$, and starch percentage in tubers\% (1). Harvesting from all the plots occurred during spring and fall seasons in 18/1/2019 and 5/5/2019 respectively. The collected data analyzed using 
analyses of variance and the means were compared according to L.S.D. test under 5\% probability (9).

Table 1. Physical and chemical characteristics of the soil

\begin{tabular}{|c|c|c|}
\hline \multirow{2}{*}{ character } & \multicolumn{2}{|c|}{ Values } \\
\hline & Fall & Spring \\
\hline pH & 7.55 & 7.33 \\
\hline $\mathrm{EC}_{1 \cdot 1}\left(\mathrm{ds} \cdot \mathrm{m}^{-1}\right)$ & 2.43 & 2.20 \\
\hline Total N $\left(\mathrm{mg} \mathrm{kg}^{-1}\right)$ & 43.0 & 40.5 \\
\hline $\mathbf{P}\left(\mathrm{mg} \mathrm{kg}^{-1}\right)$ & 10.7 & 16.7 \\
\hline $\mathrm{K}\left(\mathbf{m g ~ k g} \mathbf{~ g}^{-1}\right)$ & 146 & 190 \\
\hline $\mathrm{Ca}\left(\mathrm{mg} \mathrm{kg}^{-1}\right)$ & 204 & 136 \\
\hline $\operatorname{Mg}\left(\mathrm{mg} \mathrm{kg}^{-1}\right)$ & 161 & 73 \\
\hline $\mathrm{Na}\left(\operatorname{Meq} \mathbf{L}^{-1}\right)$ & 164 & 62 \\
\hline $\mathrm{Cl}^{-}\left(\operatorname{Meq} \mathrm{L}^{-1}\right)$ & 124 & 53 \\
\hline $\mathrm{SO}_{4}^{-2}\left(\mathrm{Meq} \mathrm{L}^{-1}\right)$ & 253 & 147 \\
\hline $\mathrm{HCO}_{3}^{-}\left(\mathrm{Meq} \mathrm{L}^{-1}\right)$ & 57 & 12.20 \\
\hline O.M. (\%) & 0.87 & 0.98 \\
\hline Gypsum (\%) & 36.5 & 34.4 \\
\hline Sand $(\%)$ & & 18 \\
\hline Silt (\%) & & 4 \\
\hline Clay (\%) & & 8 \\
\hline Texture & & Loam \\
\hline
\end{tabular}

The analysis was carried out in the Laboratories of the Department of Soil and Water Sciences, College of Agricultural Engineering Sciences, University of Baghdad.

Table 2. Physical and chemical characteristics of the Conocarpus fertilizer

\begin{tabular}{|c|c|c|}
\hline \multirow[b]{2}{*}{ Character } & \multicolumn{2}{|c|}{ Values } \\
\hline & $\begin{array}{c}\text { Before } \\
\text { decomposition }\end{array}$ & $\begin{array}{c}\text { After } \\
\text { decomposition }\end{array}$ \\
\hline $\mathbf{P h}$ & 7.26 & 6.18 \\
\hline $\mathrm{EC}_{1: 1}\left(\mathrm{Ms.cm}{ }^{-1}\right)$ & 3.2 & 2.21 \\
\hline Total N (\%) & 1.35 & 1.19 \\
\hline $\mathbf{P}(\%)$ & 0.33 & 0.52 \\
\hline $\mathbf{K}(\%)$ & 1.61 & 1.90 \\
\hline O.M. (\%) & 76.3 & 53.8 \\
\hline C/N Ratio (\%) & 42.2 & 18.1 \\
\hline $\mathrm{Cu}(\%)$ & 0.063 & 0.057 \\
\hline $\operatorname{Zn}(\%)$ & 0.012 & 0.014 \\
\hline $\mathrm{Fe}\left(\mathrm{mg} \mathrm{kg}^{-1}\right)$ & 135.7 & 156.0 \\
\hline $\operatorname{Mn}\left(\mathrm{mg} \mathrm{kg}^{-1}\right)$ & 442 & 553 \\
\hline PW $(\%)$ & 64.66 & 64.74 \\
\hline $\begin{array}{l}\text { Bulk Density } \\
\left(\mathrm{kg} \mathrm{m}^{-3}\right)\end{array}$ & 551.4 & 551.4 \\
\hline $\begin{array}{l}\text { The analysis } \\
\text { Laboratories } \\
\text { Center, Ministr }\end{array}$ & $\begin{array}{l}\text { vas carried } \\
f \quad \text { Agricultur } \\
\text { of Agriculture }\end{array}$ & $\begin{array}{l}\mathrm{t} \text { in in the } \\
\text { Researches }\end{array}$ \\
\hline
\end{tabular}

RESULTS AND DISCUSSION

1- Plant height (cm) : The results in Table 3 show the impact of Conocarpus compost and other variables on plant height. The significant values are attained in C3 $(76.35 \mathrm{~cm})(68.83$ $\mathrm{cm})$ for fall and spring seasons respectively, while the lowest values found in C2 (65.23 $\mathrm{cm})(64.62 \mathrm{~cm})$ for both seasons respectively. Table 3 also demonstrates the effect of iron foliar feeding on the plant height. The tallest plants are found in F2 $(74.5 \mathrm{~cm})(68.95 \mathrm{~cm})$ for fall and spring seasons respectively in comparison with the shortest plants in F0 $(70.53 \mathrm{~cm})(64.58 \mathrm{~cm})$ for both seasons respectively. Continuously with the same table, B2 treatment shows significant superiority in plant height $(73.74 \mathrm{~cm})(69.24$ $\mathrm{cm})$ for fall and spring seasons respectively. However, B0 shows the lowest values (70.14 $\mathrm{cm})(65.48 \mathrm{~cm})$ for fall and spring seasons respectively. About the second factor, Table 3 reveals the significant values of $\mathrm{C} 3 \mathrm{~F} 2$ and C1F2 treatments $(81.15 \mathrm{~cm})(71.09 \mathrm{~cm})$ for fall and spring seasons respectively. The lowest values shows in $\mathrm{C} 2 \mathrm{~F} 0(65.58 \mathrm{~cm})$ $(61.56 \mathrm{~cm})$ for fall and spring seasons respectively. These results indicate that fall response of potato plant height differed to $\mathrm{C}$ in comparison to Continuously with the dual interaction (Table 3), both of C1B1 and C3B2 exhibit a significant increase in plant height $(78 \mathrm{~cm})(70.13 \mathrm{~cm})$ for fall and spring seasons respectively. In comparison with the lowest plant height that found in $\mathrm{C} 2 \mathrm{BO}(64.21 \mathrm{~cm})$ $(62.32 \mathrm{~cm})$ for fall and spring seasons respectively. The results in Table 3 also demonstrate the significant superiority of F2B2 in the plant height $(76.52 \mathrm{~cm})(69.89$ $\mathrm{cm}$ ) for fall and spring seasons respectively in comparison with F0B0 which has the lowest plant height $(68.21 \mathrm{~cm})(62 \mathrm{~cm})$ for both seasons, respectively. The triple interaction among Conocarpus compost, iron and boron (table 3) had significant results. Both of C3F2B2 and C4F2B2 treatments exhibit high superiority in plant height $(85.32 \mathrm{~cm})(72.83$ $\mathrm{cm})$ for fall and spring seasons respectively in comparison with the lowest numbers that found in C2F0B0 $(63.28 \mathrm{~cm})(57.04 \mathrm{~cm})$ for fall and spring seasons respectively. 
Table 3. Impact of Conocarpus compost, iron, and boron and their interaction on plant height (cm) of potato plant for fall and spring seasons

\begin{tabular}{|c|c|c|c|c|c|c|c|c|c|}
\hline \multirow{3}{*}{$\begin{array}{c}\text { Cono. } \\
\text { Res. }\end{array}$} & \multicolumn{5}{|c|}{ Fall 2018} & \multicolumn{4}{|c|}{ Spring 2019} \\
\hline & \multirow{2}{*}{$\begin{array}{c}\mathrm{Fe}(\mathrm{mg} \\
\left.\mathrm{kg}^{-1}\right)\end{array}$} & \multicolumn{3}{|c|}{ B $\left(\mathrm{mg} \mathrm{kg}^{-1}\right)$} & \multirow{2}{*}{$\underset{\mathrm{Fe}}{\text { Cono. } \mathrm{X}}$} & \multicolumn{3}{|c|}{$B\left(m^{~ k g}{ }^{-1}\right)$} & \multirow{2}{*}{$\underset{\mathrm{Fe}}{\text { Cono. } \mathrm{X}}$} \\
\hline & & $\mathbf{B}_{0}$ & $\mathbf{B}_{1}$ & $\mathbf{B}_{2}$ & & $\mathbf{B}_{0}$ & $\mathbf{B}_{1}$ & $\mathbf{B}_{2}$ & \\
\hline \multirow{4}{*}{$\mathrm{C}_{1}$} & $\mathbf{F}_{0}$ & 71.17 & 71.45 & 75.31 & 72.64 & 66.65 & 67.12 & 66.72 & 66.83 \\
\hline & $F_{1}$ & $\mathbf{7 8 . 3 0}$ & 79.72 & 79.97 & $\mathbf{7 9 . 3 3}$ & 66.83 & 64.33 & 70.38 & 67.18 \\
\hline & $\mathbf{F}_{2}$ & 69.44 & 82.84 & 75.68 & 75.99 & 70.56 & 71.16 & 71.56 & 71.09 \\
\hline & $\mathbf{F}_{0}$ & 63.28 & 64.05 & 69.41 & 65.58 & 57.04 & 59.16 & 68.49 & 61.56 \\
\hline \multirow[t]{3}{*}{$\mathrm{C}_{2}$} & $F_{1}$ & 65.92 & 63.45 & 69.86 & 66.41 & 60.99 & 65.91 & 71.32 & 66.07 \\
\hline & $\mathbf{F}_{2}$ & 70.19 & 65.28 & 67.74 & 67.74 & 68.72 & 70.03 & 66.49 & 68.41 \\
\hline & $\mathbf{F}_{0}$ & 70.63 & 74.57 & 72.94 & 72.71 & 64.05 & 69.21 & 70.34 & 67.87 \\
\hline \multirow[t]{3}{*}{$\mathrm{C}_{3}$} & $F_{1}$ & 70.72 & 75.62 & 74.89 & 73.74 & 69.95 & 69.95 & 71.05 & 70.32 \\
\hline & $\mathbf{F}_{2}$ & 75.33 & 82.79 & 85.32 & 81.15 & 69.28 & 67.76 & 68.77 & 68.60 \\
\hline & $\mathbf{F}_{0}$ & 75.08 & 77.24 & 66.96 & 73.09 & 65.10 & $\mathbf{5 8 . 5 0}$ & 66.66 & 63.42 \\
\hline \multirow[t]{2}{*}{$\mathrm{C}_{4}$} & $F_{1}$ & 63.90 & 69.62 & 69.89 & 67.80 & 63.99 & 63.82 & 66.29 & 64.70 \\
\hline & $F_{2}$ & 67.67 & 74.40 & 76.88 & 72.98 & 62.55 & 64.06 & 72.83 & 66.48 \\
\hline \multicolumn{2}{|c|}{ LSD 5\% } & & 5.11 & & 2.95 & & 3.70 & & 2.14 \\
\hline \multicolumn{2}{|c|}{$\begin{array}{l}\text { B means } \\
\text { LSD }_{\mathbf{B}}\end{array}$} & 70.14 & $\begin{array}{c}73.42 \\
1.47\end{array}$ & 73.74 & $\begin{array}{l}\text { Cono. } \\
\text { Means }\end{array}$ & 65.48 & $\begin{array}{c}65.92 \\
1.07\end{array}$ & 69.24 & $\begin{array}{l}\text { Cono. } \\
\text { means }\end{array}$ \\
\hline & $\mathbf{C}_{1}$ & 72.37 & 78.00 & $\mathbf{7 7 . 5 1}$ & 75.96 & 68.39 & 69.14 & 69.49 & 69.01 \\
\hline Cono. & $\mathrm{C}_{2}$ & 64.21 & 66.26 & 65.22 & 65.23 & 62.32 & 62.78 & 68.77 & 64.62 \\
\hline \multirow[t]{2}{*}{ X B } & $\mathrm{C}_{3}$ & 75.48 & 76.16 & 77.42 & 76.35 & 67.40 & 68.98 & 70.13 & 68.83 \\
\hline & $\mathrm{C}_{4}$ & 68.48 & 73.26 & 74.79 & 72.18 & 63.82 & 62.79 & 68.58 & 65.06 \\
\hline \multicolumn{2}{|c|}{ LSD 5\% } & & 2.95 & & $\begin{array}{c}1.70 \\
\mathrm{Fe} \\
\text { means }\end{array}$ & & 2.14 & & $\begin{array}{c}1.23 \\
\mathrm{Fe} \\
\text { means }\end{array}$ \\
\hline \multirow{3}{*}{ Fe X B } & $\mathbf{F}_{0}$ & 68.21 & 71.83 & 71.55 & 70.53 & 62.00 & 63.61 & 68.12 & 64.58 \\
\hline & $\mathbf{F}_{1}$ & 71.54 & 72.10 & 73.14 & 72.26 & 65.61 & 66.01 & 69.72 & 67.11 \\
\hline & $F_{2}$ & 70.66 & 76.33 & 76.52 & 74.50 & 68.82 & 68.13 & 69.89 & 68.95 \\
\hline \multicolumn{2}{|c|}{ LSD 5\% } & & 2.55 & & 1.47 & & 1.85 & & 1.07 \\
\hline
\end{tabular}

\section{2- Leaf area $\left(\mathbf{d c m}^{2}\right)$}

The results in Table 4 demonstrate the effect of Conocarpus compost on leaf area. The significant values are attained in $\mathrm{C} 3$ $\left(154.77 \mathrm{dcm}^{2}\right)$ and $\mathrm{C} 1\left(188.28 \mathrm{dcm}^{2}\right)$ for fall and spring seasons respectively, while the lowest values found in $\mathrm{C} 2\left(137.08 \mathrm{dcm}^{2}\right)$ $\left(120.37 \mathrm{dcm}^{2}\right)$ respectively. Table 4 also shows the impact of iron foliar application on leaf area. The highest numbers are found in F2 $\left(153.63 \mathrm{dcm}^{2}\right)\left(177.22 \mathrm{dcm}^{2}\right)$ for fall and spring seasons respectively in comparing with the lowest numbers in F0 $\left(145.32 \mathrm{dcm}^{2}\right)$ $\left(159.87 \mathrm{dcm}^{2}\right)$ respectively. The results in Table 4 show that B2 treatment exhibits significant effect on leaf area $\left(151.69 \mathrm{dcm}^{2}\right)$ $\left(174.09 \mathrm{dcm}^{2}\right)$ for fall and spring seasons respectively. While, B0 demonstrates the lowest leaf area $\left(144.62 \mathrm{dcm}^{2}\right)\left(166.33 \mathrm{dcm}^{2}\right)$ in B0 for fall and spring seasons respectively. Second order interaction (Table 4) shows significant impact of $\mathrm{C} 3 \mathrm{~F} 2$ and $\mathrm{C} 4 \mathrm{~F} 1$ treatments $\left(168.45 \mathrm{dcm}^{2}\right)\left(220.64 \mathrm{dcm}^{2}\right)$ for fall and spring seasons respectively. The lowest second interaction found in $\mathrm{C} 2 \mathrm{~F} 0$ $\left(131.88 \mathrm{dcm}^{2}\right)\left(100.14 \mathrm{dcm}^{2}\right)$ for fall and spring seasons respectively. The dual interaction for treatments $\mathrm{C} 3 \mathrm{~B} 2$ and $\mathrm{C} 1 \mathrm{~B} 2$ exhibits a significant increase in leaf area $\left(157.56 \mathrm{dcm}^{2}\right)\left(206.33 \mathrm{dcm}^{2}\right)$ for fall and spring seasons respectively. In comparison with the lowest numbers that found in $\mathrm{C} 2 \mathrm{BO}$ $\left(132.56 \mathrm{dcm}^{2}\right)\left(113.77 \mathrm{dcm}^{2}\right)$ for fall and spring seasons respectively (Table 4). Table 4 also reveals the significant influence of treatments F2B1 and F2B2 in leaf area (161.79 $\left.\mathrm{dcm}^{2}\right)\left(188.17 \mathrm{dcm}^{2}\right)$ for fall and spring seasons respectively in comparison with F0B0 which has the lowest leaf area $\left(141.21 \mathrm{dcm}^{2}\right)$ $\left(153.01 \mathrm{dcm}^{2}\right)$ in F0B0 treatment for fall and spring seasons respectively. The interaction among Conocarpus compost, iron and boron (Table 4) had differences. Both of C4F2B2 and C1F2B2 treatments exhibit high superiority in leaf area $\left(179.67 \mathrm{dcm}^{2}\right)(250.94$ $\mathrm{dcm}^{2}$ ) for both seasons respectively in comparison with the lowest leaf area that found in C2F0B0 (128.3 $\left.\mathrm{dcm}^{2}\right)\left(93.24 \mathrm{dcm}^{2}\right)$ for both seasons respectively. 


\section{3- Number of tubers.plant $\mathbf{t}^{-1}$}

The results in Table 5 reveal the superiority of Conocarpus compost on tubers number.plant ${ }^{-1}$. The significant values are attained in C3 (6.04) (11.9) for fall and spring seasons respectively, while the lowest values found in C2 (4.94) (8.38) respectively. Table 5 also demonstrates the influence of iron spraying on Number of tubers.plant ${ }^{-1}$. The highest numbers are found from the plants of the treatments $\mathrm{F} 1$ and $\mathrm{F} 2$ (6.20) (11.04) for fall and spring seasons respectively in comparison with the lowest numbers for plants of F0 (4.76) (9.85) respectively. $\mathrm{B} 1$ and $\mathrm{B} 2$ treatments show significant impact on tubers number.plant ${ }^{-1}$ ( 5.77) (11.13) for fall and spring seasons respectively. While, B0 demonstrates the lowest values (5.38) (10.15) for both seasons respectively. The second order interaction shows significant differences for $\mathrm{C} 3 \mathrm{~F} 1$ and C1F0 treatments (6.68) (14.57) for fall and spring seasons respectively. The lowest values found in $\mathrm{C} 2 \mathrm{~F} 0$ (3.86) (7.43) for both seasons respectively.

Table 4. Impact of Conocarpus compost, iron, and boron and their interaction on leaf area $\left(\mathrm{dcm}^{2}\right)$ of potato plant for fall and spring seasons

\begin{tabular}{|c|c|c|c|c|c|c|c|c|c|}
\hline \multirow{3}{*}{$\begin{array}{l}\text { Cono. } \\
\text { Res. }\end{array}$} & \multirow{3}{*}{$\begin{array}{c}\mathbf{F e} \\
(\mathbf{m g} \\
\left.\mathbf{k g}^{-1}\right)\end{array}$} & \multicolumn{3}{|c|}{ Fall 2018} & \multirow{3}{*}{$\begin{array}{c}\text { Cono. } \\
\text { X Fe }\end{array}$} & \multicolumn{4}{|c|}{ Spring 2019} \\
\hline & & \multicolumn{3}{|c|}{$\mathrm{B}\left(\mathrm{mg} \mathrm{kg}^{-1}\right)$} & & \multicolumn{3}{|c|}{$B\left(\mathrm{mg} \mathrm{kg}^{-1}\right)$} & \multirow{2}{*}{$\begin{array}{l}\text { Cono. } \\
\text { X Fe }\end{array}$} \\
\hline & & $\mathbf{B}_{0}$ & $\mathbf{B}_{1}$ & $\mathbf{B}_{2}$ & & $\mathbf{B}_{0}$ & $\mathbf{B}_{1}$ & $\mathbf{B}_{2}$ & \\
\hline \multirow{3}{*}{$\mathrm{C}_{1}$} & $\mathbf{F}_{0}$ & 142.33 & 172.33 & 139.67 & 151.44 & 186.92 & 192.07 & 176.8 & 185.26 \\
\hline & $\mathbf{F}_{1}$ & 163.33 & 176.67 & 163.67 & 167.89 & 187.62 & 154.6 & 192.22 & 178.15 \\
\hline & $\mathbf{F}_{2}$ & 147.67 & 147.67 & 165.67 & 153.67 & 186.91 & 170.42 & 250.94 & 202.66 \\
\hline & $\mathbf{F}_{0}$ & 128.30 & 139.00 & 128.33 & 131.88 & 93.24 & 110.26 & 96.93 & 100.14 \\
\hline \multirow[t]{3}{*}{$\mathrm{C}_{2}$} & $\mathbf{F}_{1}$ & 139.33 & 144.67 & 133.33 & 139.11 & 123.36 & 123.37 & 116.83 & 121.19 \\
\hline & $\mathbf{F}_{2}$ & 144.33 & 149.67 & 134.33 & 142.78 & 126.82 & 161.52 & 130.13 & 139.49 \\
\hline & $\mathbf{F}_{0}$ & 145.11 & 142.67 & 148.00 & 145.26 & 171.46 & 222.10 & 159.34 & 184.30 \\
\hline \multirow[t]{3}{*}{$\mathbf{C}_{3}$} & $\mathbf{F}_{1}$ & 147.43 & 147.33 & 156.33 & 150 & 186.18 & 189.10 & 170.87 & 182.05 \\
\hline & $\mathbf{F}_{2}$ & 158.69 & 178.33 & 168.33 & 168 & 204.42 & 206.82 & 178.87 & 196.70 \\
\hline & $\mathbf{F}_{0}$ & 150.67 & 137.33 & 149.67 & 145 & 197.42 & 131.41 & 180.44 & 169.76 \\
\hline \multirow[t]{2}{*}{$\mathrm{C}_{4}$} & $\mathbf{F}_{1}$ & 134.33 & 142.00 & 153.33 & 143 & 210.97 & 244.92 & 206.03 & 220.64 \\
\hline & $\mathbf{F}_{2}$ & 133.72 & 147.67 & 179.67 & 153.69 & 120.59 & 159.52 & 229.93 & 169.95 \\
\hline \multicolumn{2}{|c|}{ LSD 5\% } & & 8.38 & & 4.83 & & 11.90 & & 6.87 \\
\hline \multirow{2}{*}{\multicolumn{2}{|c|}{$\begin{array}{l}\text { B means } \\
\text { LSD 5\% }\end{array}$}} & 144.62 & 152.11 & 151.69 & Cono. & 166.33 & 172.18 & 174.07 & Cono. \\
\hline & & & 2.42 & & Means & & 3.44 & & Means \\
\hline & $\mathrm{C}_{1}$ & 149.33 & 156.33 & 156.33 & 153.99 & 187.15 & 172.36 & 206.33 & 188.28 \\
\hline Cono. & $\mathrm{C}_{2}$ & 132.56 & 140.46 & 138.22 & 137.08 & 113.77 & 131.72 & 115.63 & 120.37 \\
\hline \multirow{2}{*}{ X B } & $\mathbf{C}_{3}$ & 150.26 & 156.51 & $\mathbf{1 5 7 . 5 6}$ & 154.77 & 187.95 & 206.00 & 169.86 & 187.93 \\
\hline & $\mathrm{C}_{4}$ & 146.34 & 155.13 & 154.66 & 152.04 & 176.44 & 178.62 & 205.47 & 186.84 \\
\hline \multicolumn{2}{|c|}{ LSD $5 \%$} & & 4.84 & & $\begin{array}{c}2.79 \\
\text { Fe } \\
\text { means }\end{array}$ & & 6.88 & & $\begin{array}{c}3.97 \\
\text { Fe } \\
\text { means }\end{array}$ \\
\hline \multirow{4}{*}{$\begin{array}{c}\text { Fe X } \\
\text { B }\end{array}$} & $\mathbf{F}_{0}$ & 141.21 & 142.33 & 152.42 & 145.32 & 153.01 & 163.96 & 162.63 & 159.87 \\
\hline & $\mathbf{F}_{1}$ & 147.43 & 152.21 & 148.77 & 149.47 & 177.04 & 178.00 & 171.41 & 175.48 \\
\hline & $\mathbf{F}_{2}$ & 145.22 & 161.79 & 153.88 & 153.63 & 168.93 & 174.57 & 188.17 & 177.22 \\
\hline & & & 4.19 & & 2.42 & & 4.19 & & 2.42 \\
\hline
\end{tabular}

The treatments interaction $\mathrm{C} 3 \mathrm{~B} 1$ and $\mathrm{C} 1 \mathrm{~B} 2$ show a significant increase in tubers number.plant ${ }^{-1}$ (6.43) (12.2) for fall and spring seasons respectively. In comparison with the lowest numbers that found in $\mathrm{C} 2 \mathrm{BO}$ (4.88) (7.31) for both seasons respectively (Table 5).The results in Table 5 show the significant effect of treatments F1B1 and F2B2 to the number of tubers.plants ${ }^{-1}$ (6.48) (11.65) for fall and spring seasons respectively in comparison with F0B0 which had the lowest numbers (4.51) (9.13) for fall and spring seasons respectively. Interaction among Conocarpus fertilizer, iron and boron (Table 5) produced significantly highest number of tubers.plants ${ }^{-1}$ for both of C3F1B1 and C1F0B2 treatments (7.24) (18.5) for fall and spring seasons respectively in comparison with the lowest numbers that found in $\mathrm{C} 2 \mathrm{~F} 0 \mathrm{~B} 0$ (3.64) (7.2) for both seasons respectively. 
Table 5. Impact of Conocarpus compost, iron, and boron and their interaction on tubers number.plant ${ }^{-1}$ of potato plant for fall and spring seasons

\begin{tabular}{|c|c|c|c|c|c|c|c|c|c|}
\hline \multirow{3}{*}{$\begin{array}{c}\text { Cono. } \\
\text { Res. }\end{array}$} & \multirow{3}{*}{$\begin{array}{c}\mathbf{F e} \\
(\mathbf{m g} \\
\left.\mathbf{k g}^{-1}\right)\end{array}$} & \multicolumn{4}{|c|}{ Fall 2018} & \multicolumn{4}{|c|}{ Spring 2019} \\
\hline & & & $\left(\mathbf{m g ~ k} \mathbf{k}_{\xi}\right.$ & & Cono & & (mg kg & & \\
\hline & & $\mathbf{B}_{0}$ & $\mathbf{B}_{1}$ & $\mathbf{B}_{2}$ & X Fe & $\mathbf{B}_{0}$ & $\mathbf{B}_{1}$ & $\mathbf{B}_{2}$ & $\mathrm{X} \mathrm{Fe}$ \\
\hline \multirow{4}{*}{$\mathrm{C}_{1}$} & $\mathbf{F}_{\mathbf{0}}$ & 4.38 & 5.06 & 5.65 & 5.03 & 11.1 & 14.1 & 18.5 & 14.57 \\
\hline & $\mathbf{F}_{1}$ & 6.07 & 5.92 & 6.40 & 6.13 & 10.8 & 11.2 & 8.0 & 10.00 \\
\hline & $\mathbf{F}_{2}$ & 6.22 & 5.66 & 6.68 & 6.19 & 9.8 & 10.3 & 7.3 & 9.13 \\
\hline & $\mathbf{F}_{\mathbf{0}}$ & 3.64 & 4.17 & 3.77 & 3.86 & 7.2 & 7.3 & 7.8 & 7.43 \\
\hline \multirow[t]{3}{*}{$\mathbf{C}_{2}$} & $\mathbf{F}_{1}$ & 5.56 & 6.05 & 5.84 & 5.82 & 8.7 & 7.7 & 9.6 & 8.67 \\
\hline & $\mathbf{F}_{2}$ & 5.04 & 4.88 & 5.12 & 5.01 & 10.7 & 10.6 & 8.5 & 9.93 \\
\hline & $\mathbf{F}_{0}$ & 6.04 & 5.28 & 5.46 & 5.59 & 11.4 & 14.6 & 10.7 & 12.23 \\
\hline \multirow[t]{3}{*}{$\mathrm{C}_{3}$} & $\mathbf{F}_{1}$ & 5.84 & 7.24 & 6.97 & 6.68 & 13.2 & 8.8 & 10.6 & 10.87 \\
\hline & $\mathbf{F}_{2}$ & 5.78 & 6.75 & 5.31 & 5.95 & 11.0 & 12.4 & 17.0 & 13.47 \\
\hline & $\mathbf{F}_{0}$ & 4.75 & 5.16 & 4.54 & 4.82 & 6.8 & $\mathbf{9 , 0}$ & 11.4 & 9.07 \\
\hline \multirow[t]{2}{*}{$\mathrm{C}_{4}$} & $\mathbf{F}_{1}$ & 5.28 & 6.72 & 6.25 & 6.08 & 10.6 & 11.2 & 12.3 & 11.37 \\
\hline & $\mathbf{F}_{2}$ & 5.91 & 6.30 & 5.71 & 5.97 & 10.5 & 8.6 & 11.9 & 10.33 \\
\hline \multicolumn{2}{|c|}{ LSD 5\% } & & 0.80 & & 0.51 & & 1.65 & & 0.95 \\
\hline \multicolumn{2}{|c|}{ B means } & 5.38 & 5.77 & 5.64 & Cono. & 10.15 & 10.48 & 11.13 & Cono. \\
\hline \multicolumn{2}{|c|}{ LSD 5\% } & & 0.23 & & Means & & 0.48 & & Means \\
\hline & $\mathrm{C}_{1}$ & 5.56 & 5.55 & 6.24 & 5.78 & 11.11 & 11.80 & 12.20 & 11.70 \\
\hline Cono. & $\mathrm{C}_{2}$ & 4.88 & 5.03 & 4.92 & 4.94 & 7.31 & 8.63 & 9.19 & 8.38 \\
\hline \multirow[t]{2}{*}{ X B } & $\mathbf{C}_{3}$ & 5.79 & 6.43 & 5.91 & 6.04 & 12.11 & 11.90 & 11.70 & 11.90 \\
\hline & $\mathrm{C}_{4}$ & 5.31 & 6.06 & $\mathbf{5 . 5 0}$ & 5.62 & 10.10 & 9.60 & 11.44 & 10.38 \\
\hline LSI & & & 0.51 & & $\begin{array}{c}0.27 \\
\text { Fe } \\
\text { means }\end{array}$ & & 0.95 & & $\begin{array}{c}\mathbf{0 . 5 5} \\
\mathrm{Fe} \\
\text { means }\end{array}$ \\
\hline \multirow{3}{*}{$\begin{array}{c}\text { Fe X } \\
\text { B }\end{array}$} & $\mathbf{F}_{\mathbf{0}}$ & 4.51 & 4.92 & 4.85 & 4.76 & 9.13 & 10.32 & 10.11 & 9.85 \\
\hline & $\mathbf{F}_{1}$ & 5.79 & 6.48 & 6.32 & 6.20 & 10.35 & 10.63 & 11.63 & 10.87 \\
\hline & $\mathbf{F}_{2}$ & 5.84 & 5.90 & 5.77 & 5.84 & 10.98 & 10.50 & 11.65 & 11.04 \\
\hline \multicolumn{2}{|c|}{ LSD $5 \%$} & & 0.40 & & 0.23 & & 0.82 & & 0.48 \\
\hline
\end{tabular}

4- plant yield (g. plant $^{-1}$ ) The results in Table 6 show superiority of of Conocarpus compost on plant yield. The treatments $\mathrm{C} 3$ and $\mathrm{C} 1$ produced significantly highest plant yield $\left(649.7\right.$ g. plant $\left.^{-1}\right)\left(1053\right.$ g. plant $\left.{ }^{-1}\right)$ for fall and spring seasons respectively, while the lowest potato plant yield found from the plants of the treatments C2 (459.17 g. plant $\left.{ }^{-1}\right)(798.4 \mathrm{~g}$. plant $^{-1}$ ) respectively. Table 6 also shows the impact of iron feeding on plant yield. The highest plant yield was found from treatment F1 (673.23 g. plant $\left.{ }^{-1}\right)\left(972.9\right.$ g. plant $\left.{ }^{-1}\right)$ for fall and spring seasons respectively in comparison with the lowest plant yield from the plants of F0 (470.83 g. plant $\left.{ }^{-1}\right)\left(899.5\right.$ g. plant $\left.^{-1}\right)$ respectively. B1 and $\mathrm{B} 2$ show the highest plant yield (605.9 g. plant $\left.{ }^{-1}\right)\left(950\right.$ g. plant $\left.{ }^{-1}\right)$ (Table 6) for fall and spring seasons respectively. While, B0 demonstrates the lowest plant yield (532.7 g. plant $\left.{ }^{-1}\right)$ (909 g. plant $\left.^{-1}\right)$ for both seasons respectively. Second order interaction had the highest significant treatments C3F1 and C1F1 (749.4 g. plant $\left.{ }^{-1}\right)\left(1111.5\right.$ g. plant $\left.{ }^{-1}\right)$ for fall and spring seasons respectively. The lowest plant yield found from treatment $\mathrm{C} 2 \mathrm{~F} 0$ (349.4 g. plant $^{-1}$ ) 708.3 g. plant $^{-1}$ ) for both seasons respectively. The results for the interaction for treatment C1B2 had a significant increase in plant yield (710.6 g. plant $\left.^{-1}\right)\left(1119.9\right.$ g. plant $\left.{ }^{-1}\right)$ for fall and spring seasons respectively. In comparison with the lowest plant yield that found from the plants of the treatment C2BO (435.9 g. plant $\left.{ }^{-1}\right)$ (776.4 g. plant $^{-1}$ ) for both seasons respectively (Table 6). Table 6 also shows the significant effect of treatments F1B1 and F1B2 on plant yield $\left(712.3\right.$ g. plant $\left.{ }^{-1}\right)\left(996.4\right.$ g. plant $\left.^{-1}\right)$ for fall and spring seasons respectively in comparison with F0B0 which had the lowest plant yield (437.8 g. plant $\left.^{-1}\right)\left(844.8 \mathrm{~g}\right.$. plant $\left.^{-1}\right)$ for fall and spring seasons respectively. The interaction among Conocarpus fertilizer, iron and boron (Table 6) shows significant differences among treatments. Both of $\mathrm{C} 1 \mathrm{~F} 1 \mathrm{~B} 2$ and $\mathrm{C} 3 \mathrm{~F} 2 \mathrm{~B} 0$ treatments show high superiority in plant yield $\left(811\right.$ g. plant $\left.{ }^{-1}\right)\left(1239.2\right.$ g. plant $\left.^{-1}\right)$ for fall and 
spring seasons respectively in comparison with the lowest plant yield that found from the plants of the treatment C2F0B0 (299.7 g. plant $\left.^{-1}\right)\left(637.5\right.$ g. plant $\left.{ }^{-1}\right)$ for both seasons respectively.

\section{5- Starch percentage of potato tuber}

The results of potato tubers starch \% (Table 7) show the impact of Conocarpus compost on tuber starch percentage $\%$. Significant differences were found between $\mathrm{C} 4$ and $\mathrm{C} 1$ $(10.13 \%)(11.10 \%)$ for fall and spring seasons respectively, while the lowest values found in C2 $(9.47 \%)(9.32 \%)$ respectively. Table 7 shows the effect of iron foliar spraying on tuber starch. The highest percentage were from F1 plants (10.08\%) (11.41\%) for fall and spring seasons respectively in comparison with the lowest percent in F0 (9.74\%) $(9.52 \%)$ respectively. B2 treatment shows significant superiority on starch percentage (10.09\%) $(10.85 \%)$ for fall and spring seasons respectively. However, B0 shows the lowest percent $(9.59 \%)(9.63 \%)$ for both seasons respectively. The interaction results in table 7 reveal the significant values of $\mathrm{C} 3 \mathrm{~F} 1$ and C1F1 treatments $(10.48 \%)(12.64 \%)$ for fall and spring seasons respectively. The lowest values found from the plants in C2F0 (9.15\%) $(8.77 \%)$ for both seasons respectively. The interaction of $\mathrm{C} 4 \mathrm{~B} 2$ and $\mathrm{C} 1 \mathrm{~B} 2$ had $\mathrm{a}$ significant increase on starch percentage \% $(10.42 \%)(11.74 \%)$ for fall and spring seasons respectively. In comparison with the lowest percent that found from the plants in $\mathrm{C} 2 \mathrm{BO}$ $(8.85 \%)(8.92 \%)$ for both seasons respectively. Table 7 also reveals the significant superiority of F1B1 in starch percentage\% (10.43\%) $(12.26 \%)$ for fall and spring seasons respectively in comparison with F0B0 which had the lowest numbers $(9.32 \%)(8.37 \%)$ for both seasons respectively.The third order interaction among Conocarpus fertilizer, iron and boron didn't show significant results on tuber starch percentage (Table 7).

Table 6. Impact of Conocarpus compost, iron, and boron and their interaction on plant yield (g.) of potato plant for fall and spring seasons

\begin{tabular}{|c|c|c|c|c|c|c|c|c|c|}
\hline \multirow{3}{*}{$\begin{array}{c}\text { Cono. } \\
\text { Res. }\end{array}$} & \multirow{3}{*}{$\begin{array}{c}\mathbf{F e} \\
(\mathbf{m g} \\
\left.\mathrm{kg}^{-1}\right)\end{array}$} & \multicolumn{3}{|c|}{ Fall 2018} & \multirow{3}{*}{$\begin{array}{l}\text { Cono. } \\
\text { X Fe }\end{array}$} & \multicolumn{4}{|c|}{ Spring 2019} \\
\hline & & & (mg kg & & & & (mg kg- & & \\
\hline & & $\mathbf{B}_{0}$ & $\mathbf{B}_{1}$ & $\mathbf{B}_{2}$ & & $\mathbf{B}_{0}$ & $\mathbf{B}_{1}$ & $\mathbf{B}_{2}$ & \\
\hline \multirow{3}{*}{$\mathrm{C}_{1}$} & $\mathbf{F}_{0}$ & 478.7 & 527.3 & 583.0 & 529.7 & 1123.3 & 1115.0 & 1062.9 & 1100.4 \\
\hline & $\mathbf{F}_{1}$ & 647.0 & 742.7 & 811.0 & 733.6 & 996.2 & 1127.5 & 1210.8 & 1111.5 \\
\hline & $\mathbf{F}_{2}$ & 574.3 & 600.7 & 738.7 & 637.9 & 994.2 & 994.2 & 1085.8 & 946.9 \\
\hline & $\mathbf{F}_{\mathbf{0}}$ & 299.7 & 400.3 & 348.3 & 349.4 & 637.5 & 770.8 & 716.7 & 708.3 \\
\hline \multirow[t]{2}{*}{$\mathbf{C}_{2}$} & $\mathbf{F}_{1}$ & 542.3 & 595.0 & 485.3 & 540.9 & 837.5 & 745.8 & 879.2 & 820.8 \\
\hline & $\mathbf{F}_{2}$ & 416.0 & 485.0 & 559.7 & 486.9 & 854.2 & 952.1 & 791.7 & 866.0 \\
\hline & $\mathbf{F}_{\mathbf{0}}$ & 504.7 & 568.3 & 570.7 & 547.9 & 953.7 & 1114.2 & 930.8 & 999.6 \\
\hline \multirow[t]{3}{*}{$\mathbf{C}_{3}$} & $\mathbf{F}_{1}$ & 694.0 & 765.3 & 789.0 & 749.4 & 1010.0 & 1010.0 & 989.2 & 1010.0 \\
\hline & $\mathbf{F}_{2}$ & 638.7 & 684.0 & 623.3 & 648.7 & 1239.2 & 1016.7 & 1010.0 & 1088.6 \\
\hline & $\mathbf{F}_{0}$ & 463.3 & 518.0 & 431.3 & 470.9 & 664.6 & 712.5 & 991.7 & 789.6 \\
\hline \multirow[t]{2}{*}{$\mathrm{C}_{4}$} & $\mathbf{F}_{1}$ & 631.0 & 746.3 & 637.0 & 671.4 & 875.0 & 1066.7 & 906.2 & 949.3 \\
\hline & $\mathbf{F}_{2}$ & 502.7 & 638.3 & 567.0 & 569.3 & 935.4 & 733.3 & 825.0 & 831.2 \\
\hline \multicolumn{2}{|c|}{ LSD 5\% } & & 50.4 & & 29.0 & & 85.2 & & 49.2 \\
\hline \multicolumn{2}{|c|}{$\begin{array}{l}\text { B means } \\
\text { LSD 5\% }\end{array}$} & 532.7 & $\begin{array}{c}605.9 \\
14.5\end{array}$ & 595.4 & $\begin{array}{l}\text { Cono. } \\
\text { means }\end{array}$ & 909.0 & $\begin{array}{c}946.6 \\
24.6\end{array}$ & 950.0 & $\begin{array}{l}\text { Cono. } \\
\text { Means }\end{array}$ \\
\hline \multirow{4}{*}{$\begin{array}{l}\text { Cono. } \\
\text { X B }\end{array}$} & $\mathrm{C}_{1}$ & 562.7 & 623.6 & 710.6 & 632.30 & 960.1 & 1119.9 & 1119.9 & 1053.0 \\
\hline & $\mathrm{C}_{2}$ & 435.9 & 493.4 & 448.2 & 459.17 & 776.4 & 822.9 & 795.8 & 798.4 \\
\hline & $\mathrm{C}_{3}$ & 598.9 & 672.6 & 677.6 & 649.70 & 1074.6 & 1046.9 & 976.7 & 1032.7 \\
\hline & $\mathrm{C}_{4}$ & 532.9 & 634.2 & 545.1 & 570.75 & 825.0 & 837.5 & 907.6 & 856.7 \\
\hline \multicolumn{2}{|c|}{ LSD $5 \%$} & & 29.0 & & $\begin{array}{c}17.5 \\
\text { Fe } \\
\text { means }\end{array}$ & & 49.2 & & $\begin{array}{c}28.4 \\
\text { Fe } \\
\text { means }\end{array}$ \\
\hline \multirow{3}{*}{$\begin{array}{c}\text { Fe X } \\
\text { B }\end{array}$} & $\mathbf{F}_{\mathbf{0}}$ & 437.8 & 503.5 & 471.2 & 470.83 & 844.8 & 928.1 & 925.5 & 899.5 \\
\hline & $\mathbf{F}_{1}$ & 628.8 & 712.3 & 680.6 & 673.23 & 934.9 & 987.5 & 996.4 & 972.9 \\
\hline & $\mathbf{F}_{2}$ & 532.9 & 602.0 & 635.2 & 590.03 & 947.4 & 924.1 & 928.1 & 933.2 \\
\hline \multicolumn{2}{|c|}{ LSD 5\% } & & 25.2 & & 14.5 & & 42.6 & & 24.6 \\
\hline
\end{tabular}


Table 7. Impact of Conocarpus compost, iron, and boron and their interaction on starch percentage \% of potato plant for fall and spring seasons

\begin{tabular}{|c|c|c|c|c|c|c|c|c|c|}
\hline \multirow{3}{*}{$\begin{array}{l}\text { Cono. } \\
\text { Res. }\end{array}$} & \multirow{2}{*}{\multicolumn{4}{|c|}{ Fall 2018}} & \multirow{3}{*}{$\begin{array}{c}\text { Cono. } X \\
\text { Fe }\end{array}$} & \multicolumn{4}{|c|}{ Spring 2019} \\
\hline & & & & & & \multicolumn{3}{|c|}{$B\left(\mathrm{mg} \mathrm{kg}^{-1}\right)$} & \multirow{2}{*}{$\begin{array}{c}\text { Cono. X } \\
\text { Fe }\end{array}$} \\
\hline & $\left.\mathrm{kg}^{-1}\right)$ & $\mathbf{B}_{0}$ & $\mathbf{B}_{1}$ & $\mathbf{B}_{2}$ & & $\mathbf{B}_{0}$ & $\mathbf{B}_{1}$ & $\mathbf{B}_{2}$ & \\
\hline \multirow{4}{*}{$\mathrm{C}_{1}$} & $\mathbf{F}_{0}$ & 9.38 & 9.51 & 10.24 & 9.90 & 8.48 & 9.81 & 11.15 & 9.81 \\
\hline & $\mathbf{F}_{1}$ & 9.24 & 10.30 & 9.75 & 9.76 & 11.60 & 13.82 & 12.49 & 12.64 \\
\hline & $\mathbf{F}_{2}$ & 9.90 & 9.52 & 10.55 & 9.99 & 10.26 & 10.71 & 11.60 & 10.85 \\
\hline & $\mathbf{F}_{0}$ & 7.95 & 9.47 & 10.04 & 9.15 & 8.03 & 9.37 & 8.92 & 8.77 \\
\hline \multirow{3}{*}{$\mathrm{C}_{2}$} & $\mathbf{F}_{1}$ & 9.42 & 9.95 & 9.69 & 9.69 & 9.81 & 10.71 & 9.81 & 10.11 \\
\hline & $\mathbf{F}_{2}$ & 9.18 & 9.71 & 9.83 & 9.57 & 8.92 & 9.37 & 8.92 & 9.07 \\
\hline & $\mathbf{F}_{\mathbf{0}}$ & 9.86 & 9.78 & 10.13 & 9.92 & 8.92 & 9.37 & 12.49 & 10.26 \\
\hline \multirow[t]{3}{*}{$\mathrm{C}_{3}$} & $F_{1}$ & 10.27 & 10.65 & 10.53 & 10.48 & 10.71 & 11.60 & 11.15 & 11.15 \\
\hline & $\mathbf{F}_{2}$ & 10.18 & 9.19 & 9.10 & 9.49 & 10.71 & 10.71 & 10.71 & 10.71 \\
\hline & $\mathbf{F}_{\mathbf{0}}$ & 9.50 & 9.94 & 10.43 & 9.96 & 8.03 & 9.37 & 10.26 & 9.22 \\
\hline \multirow[t]{2}{*}{$\mathrm{C}_{4}$} & $F_{1}$ & 9.66 & 10.80 & 10.73 & 10.40 & 10.71 & 12.93 & 11.60 & 11.74 \\
\hline & $\mathbf{F}_{2}$ & 9.92 & 10.12 & 10.09 & 10.04 & 9.37 & 10.26 & 11.15 & 10.26 \\
\hline \multicolumn{2}{|c|}{ LSD 5\% } & & N.S & & 0.51 & & N.S & & 0.80 \\
\hline \multirow{2}{*}{\multicolumn{2}{|c|}{$\begin{array}{l}\text { B means } \\
\text { LSD 5\% }\end{array}$}} & 9.59 & 9.91 & 10.09 & Cono. & 9.63 & 10.67 & 10.85 & Cono. \\
\hline & & & 0.25 & & Means & & 0.40 & & Means \\
\hline & $\mathrm{C}_{1}$ & 9.70 & 9.78 & 10.18 & 9.89 & 10.11 & 11.45 & 11.74 & 11.10 \\
\hline Cono. & $\mathrm{C}_{2}$ & 8.85 & 9.71 & 9.85 & 9.47 & 8.92 & 9.81 & 9.22 & 9.32 \\
\hline \multirow[t]{2}{*}{$\mathbf{X} \mathbf{B}$} & $\mathrm{C}_{3}$ & 10.10 & 9.88 & 9.92 & 9.97 & 10.11 & 10.56 & 11.45 & 10.71 \\
\hline & $\mathrm{C}_{4}$ & 9.69 & 10.29 & 10.42 & 10.13 & 9.37 & 10.85 & 11.00 & 10.41 \\
\hline \multicolumn{2}{|c|}{ LSD 5\% } & & 0.51 & & $\begin{array}{c}0.29 \\
\text { Fe } \\
\text { means }\end{array}$ & & 0.80 & & $\begin{array}{c}\mathbf{0 . 4 5} \\
\text { Fe } \\
\text { means }\end{array}$ \\
\hline \multirow{3}{*}{ Fe X B } & $\mathbf{F}_{\mathbf{0}}$ & 9.32 & 9.68 & 10.21 & 9.74 & 8.37 & 9.48 & 10.71 & 9.52 \\
\hline & $F_{1}$ & 9.65 & 10.43 & 10.18 & 10.08 & 10.71 & 12.26 & 11.26 & 11.41 \\
\hline & $\mathbf{F}_{2}$ & 9.80 & 9.64 & 9.89 & 9.77 & 9.81 & 10.26 & 10.59 & 10.22 \\
\hline \multicolumn{2}{|c|}{ LSD 5\% } & & 0.44 & & 0.25 & & 0.69 & & 0.40 \\
\hline
\end{tabular}

It could be observed from these results the strong and fast impact of chemical fertilizer. In fact, it's fast solubility and availability to the plant led to these findings in comparison with the organic fertilizer (18). The significant results that came from foliar feeding with iron are due to its crucial role as a part of hemic proteins and $\mathrm{Fe}-\mathrm{S}$ proteins, which have vital role in photosynthesis, respiration. Furthermore, iron is a component of the electrons transport enzymes (Redox reactions) such as cytochromes $(20,21)$. These findings are in harmony with Awad et al (5) and Estaji et al (10). The significant superiority of foliar application with boron might be resulted from its effect on growth of meristematic tissues, building of nucleic acids, and sugars translocation. Furthermore, boron increases the absorption of potassium (6). These results in agreement with Awad et al (5). The positive findings of Conocarpus fertilizer could be interpreted by improving the mentioned fertilizer the physical and chemical properties of the soil (Table 2), such as increasing its water retention, creating ideal atmosphere for root growth, increasing the activity and numbers of microorganisms, and increasing the availability of the minerals and that reflects on the strength of vegetative growth and increasing the photosynthesis products and accumulates in tubers $(7,13)$, this is consistent with the results of Kang (11) and Moyin-Jesu (16).

\section{REFERENCES}

1. A. O. A. C. 1970. Official Method of Analysis $11^{\text {th }}$ ed. Washington, D.C. Association of The Official Analytical Chemistry. pp: 1015

2. Al-Fadhli, J. T. M. 2011. Effect of Organic and Mineral Fertilization on Potato Growth and Productivity. Ph.D. Dissertation. Department of Soil Sciences and Water Resources, College of Agriculture, University of Baghdad. pp:175

3. Alkoaik, F. N., Khalil, A. I., M. A. AlMahasneh, R. B. Fulleros, and A. Mo. ElWaziry. 2014. Changes in colour and germination index as indicators for compost maturity. Journal of pure \& applied microbiology. 8(2): 409-417

4. Al-Zaidy, A. K. N.and R. M. Al-Ubaidy. 2017. Effect of adding wheat peat and 
spraying with its extract and organic nutrient vegeamino on growth and yield of red cabbage. Iraqi Journal of Agricultural Sciences, 48(2): 429-438

5. Awad, El. M.M. M.S. Emam and Z. S. El. Shall. 2010. The influence of foliar spraying with nutrients on growth yield and storability of potato tubers. J. Plant Prod., Mansoura Univ., 1 (10): 1313-1325

6. Barker, A. V., and D. J. Pilbeam, 2007. Plant Nutrition. Taylor \& Francis Group, LLC. pp: 653

7. Berbara, R. L. L. and A. C. Garcia. 2014. Humic Substances and Blant Defense Metabolism. In: Ahmad P, Wani MR (eds) Physiological Mechanisms and Adaptation Strategies in Blants Under Changing Environment: volume 1. Springer Science+Business Media, New York, pp: 297319

8. Bowen, W. T. 2003. Water Productivity and Potato Cultivation in j.w. kijhe, R. Barke, amd D. Molden. Water Productivity in Agriculture: Limits and Opportunities for Improvement CAB. International, pp: 229-238

9. El-Sahoeky, N. and K. N. Wahab. 1990. Application in the Design and Analysis of Experiments. Bghdad University. Ministry of Higher Education and Scientific Research. Dar- Al- Hikma for printing and publishing, pp:488.

10. Estaji, A., H. R. Rousta, and M. R. M. Kahnooj. 2015. Assessment of foliar application of iron and silicon on some agronomic, quantitative and qualitative parameters of potato (Solanum tuberosum L.). J. Crop. Nut. Sci., 1(2): 18-25

11. Kang, J., A. Amoozegar, D. Hesterberg and D. L. Osmond. 2011. Phosphorus leaching in a sandy soil as affected by organic and inorganic fertilizer sources. Geoderma 161, 194-201

12. Lehmann J, J. Skjemstad, S. Sohi, J. Carter, M. Barson, P. Falloon, K. Coleman, P. Woodbury, and A. E. Krull. 2008. Australian climate - carbon cycle feedback reduced by soil black carbon.Nature Geosci. 1: 832-835

13. Lehmann, J., J. P. da Silva, C. Steiner, T. Nehls, W. Zech, , and B. Glaser. 2003. Nutrient availability and leaching in an archaeological Anthrosol and a Ferralsol of the Central Amazon basin: fertilizer, manure and charcoal amendments. Plant Soil 249, 343

14. Manjunath, R.P., Vishnuvardhana, M. Anjanappa, G. K. Ramegowda. S. Anilkumar, and, P.S. Prasad. 2018. Influence of foliar spray of micronutrient formulation on quality and shelf Life of potato (Solanum tuberosum L.), Int. J. Pure App. Biosci. 6 (1): 660-665.

15. Moinuddin, G., S. Jash, A. Sarkar, and S. Dasgupta. 2017. Response of potato (Solanum tuberosum L.) to foliar application of macro and micronutrients in the Red and Lateritic Zone of West Bengal. Journal of Crop and Weed, 13(1) : 185-188

16. Moyin-Jesu, E. I. 2014. Effects of water extracts of neem (Azadirachta indica L.) leaf, wood ash and their mixture on soil chemical composition and growth and yield of plantain (Musa sapientum L.). American Journal of Experimental Agriculture 4(7): 836-848

17. Saaseea, K. G. and N. J. K. Al-a'amry. 2018. Effect of foliar application with calcium, magnesium and fertilizing with humic acid on growth, yield and storage ability of potato tubers. Iraqi Journal of Agricultural Sciences, 49(5): 897-905

18. Saunders, A. 2001. Organic potato production greenmount, Antrin, BT. 41,.UK.

19. Shayaa, A. H. and W. A. Hussein, 2019. Effect of neem leaves extract and organic fertilizer in the productivity and quality of two potato cultivars. Iraqi Journal of Agricultural Sciences, 50(1): 275-285

20. Taiz, L. , and E. Zeiger. 2010. Plant Physiology. $5^{\text {th }}$ ed, Sinauer Assotiates, Inc., Publishers Sunderland, Massachusetts. pp, 761 21. Tanaka, M., T. Fujiwara, P. and Arch Eur. 2008. Jour. Physiol. Physiological roles and transport mechanisms of boron: perspectives from plants 456: 671 . https://doi.org/10.1007/s00424-007-0370-8

22. Usman, A. A., M. I. Al-Wabel, Y. S. Ok, A, Al-Harbi, M. Wahb Allah, A. H. ELNaggar, M. Ahmed, A. AL-Faraj and A. ALOmran. 2016. Conocarpus biochar induces changes in soil nutrient availability and tomato growth under saline irrigation. pedosphere 26(1): 27-38. 